NOVEMBER 1996

RESEARCH PAPER FIFTY-TWO

\title{
EFFECTS OF INFLATION ON IVORIAN FISCAL VARIABLES: AN ECONOMETRIC INVESTIGATION
}

EUGENE KOUASSI

AFRICAN ECONOMIC RESEARCH CONSORTIUM

CONSORTIUM POUR LA RECHERCHE ECONOMIQUE EN AFRIQUE 
Effects of inflation on Ivorian fiscal variables:

An econometric investigation 
Other publications in the AERC Research Papers Series:

Structural Adjustment Programmes and the Coffee Sector in Uganda by Germina Ssemogerere, Research Paper 1.

Real Interest Rates and the Mobilization of Private Savings in Africa by F.M. Mwega, S.M. Ngola and N. Mwangi, Research Paper 2.

Mobilizing Domestic Resources for Capital Formation in Ghana: The Role of Informal Financial Markets by Ernest Aryeetey and Fritz Gockel, Research Paper 3.

The Informal Financial Sector and Macroeconomic Adjustment in Malawi by C. Chipeta and M.L.C. Mkandawire, Research Paper 4.

The Effects of Non-Bank Financial Intermediaries on Demand for Money in Kenya by S.M. Ndele, Research Paper 5.

Exchange Rate Policy and Macroeconomic Performance in Ghana by C.D. Jebuni, N.K. Sowa and K.S. Tutu, Research Paper 6.

A Macroeconomic-Demographic Model for Ethiopia by Asmerom Kidane, Research Paper 7.

Macroeconomic Approach to External Debt: the Case of Nigeria by S. Ibi Ajayi, Research Paper 8.

The Real Exchange Rate and Ghana's Agricultural Exports by K. Yerfi Fosu, Research Paper 9.

The Relationship Between the Formal and Informal Sectors of the Financial Market in Ghana by E. Aryeetey, Research Paper 10.

Financial System Regulation, Deregulation and Savings Mobilization in Nigeria by A. Soyibo and F. Adekanye, Research Paper 11.

The Savings-Investment Process in Nigeria: An Empirical Study of the Supply Side by A. Soyibo, Research Paper 12

Growth and Foreign Debt: The Ethiopian Experience, 1964-86 by B. Degefe, Research Paper 13.

Links Between the Informal and Formal/Semi-Formal Financial Sectors in Malawi by C. Chipeta and M.L.C. Mkandawire, Research Paper 14.

The Determinants of Fiscal Deficit and Fiscal Adjustment in Cote d' Ivoire by O. Kouassy and B. Bohoun, Research Paper 15.

Small and Medium-Scale Enterprise Development in Nigeria by D.E. Ekpenyong and M.O. Nyong, Research Paper 16.

The Nigerian Banking System in the Context of Policies of Financial Regulation and Deregulation by A. Soyibo and F. Adekanye, Research Paper 17.

Scope, Structure and Policy Implications of Informal Financial Markets in Tanzania by M. Hyuha, O. Ndanshau and J.P. Kipokola, Research Paper 18.

European Economic Integration and the Franc Zone: The future of the CFA Franc after 1996. Part I: Historical Background and a New Evaluation of Monetary Cooperation in the CFA Countries by Allechi M'bet and Madeleine Niankey, Research Paper 19.

Revenue Productivity Implications of Tax Reform in Tanzania by Nehemiah E. Osoro, Research Paper 20. 
The Informal and Semi-formal Sectors in Ethiopia: A Study of the Iqqub, Iddir and Savings and Credit Cooperatives by Dejene Aredo, Research Paper 21.

Inflationary Trends and Control in Ghana by Nii K. Sowa and John K. Kwakye, Research Paper 22.

Macroeconomic Constraints and Medium-Term Growth in Kenya: A Three Gap Analysis by F.M. Mwega, N. Njuguna and K. Olewe-Ochilo, Research Paper 23.

The Foreign Exchange Market and the Dutch Auction System in Ghana by Cletus K. Dordunoo, Research Paper 24.

Exchange Rate Depreciation and the Structure of Sectoral Prices in Nigeria Under an Alternative Pricing Regime, 1986-89 by Olu Ajakaiye and Ode Ojowu, Research Paper 25.

Exchange Rate Depreciation, Budget Deficit and Inflation - The Nigerian Experience by F. Egwaikhide, L. Chete and G. Falokun, Research Paper 26.

Trade, Payments Liberalization and Economic Performance in Ghana by C.D. Jebuni, A.D. Oduro and K.A. Tutu, Research Paper 27.

Constraints to the Development and Diversification of Non-Traditional Exports in Uganda, $1981-90$ by G. Ssemogerere and L.A. Kasekende, Research Paper 28.

Indices of Effective Exchange Rates: A Comparative Study of Ethiopia, Kenya and the Sudan by Asmerom Kidane, Research Paper 29.

Monetary Harmonization in Southern Africa by C. Chipeta and M.L.C. Mkandawire, Research Paper 30.

Tanzania's Trade with PTA Countries: A Special Emphasis on Non-Traditional Products by Flora Mndeme Musonda, Research Paper 31

Macroeconomic Adjustment, Trade and Growth: Policy Analysis using a Macroeconomic Model of Nigeria by C. Soludo, Research Paper 32

Ghana: The Burden of Debt Service Payment Under Structural Adjustment by Barfour Osei, Research Paper 33.

Short-Run Macroeconomic Effects of Bank Lending Rates in Nigeria, 1987-91. A Computable General Equilibrium Analysis by D. Olu Ajakaiye, Research Pape 34.

Capital Flight and External Debt in Nigeria by S. Ibi Ajayi, Research Paper 35. Institutional Reforms and the Management of Exchange Rate Policy in Nigeria by Kassey Odubogun, Research Paper 36.

The Role of Exchange Rate and Monetary Policy in the Monetary Approach to the Balance of Payments: Evidence from Malawi by Exley B.D. Silumbu, Research Paper 37.

Tax Reforms in Tanzania: Motivations, Directions and Implications by Nehemiah E. Osoro, Research Paper 38.

Money Supply Mechanisms in Nigeria, 1970-88 by Oluremi Ogun and Adeola Adenikinju, Research Paper 39.

Profiles and Determinants of Nigeria's Balance of Payments: The Current Account Component, 1950-88, by Joe U. Umo and Tayo Fakiyesi, Research Paper 40.

Enpirical Studies of Nigeria's Foreign Exchange Parallel Market 1: Price Behaviour and Rate Determination by Melvin D. Ayogu, Research Paper 41. 
The Effects of Exchange Rate Policy on Cameroon's Agricultural Competitiveness by Aloysius Ajab Amin, Research Paper 42.

Policy Consistency and Inflation in Ghana by Nii Kwaku Sowa, Research Paper 43.

Fiscal Operations in a Depressed Economy: Nigeria, 1960-90 by Akpan H. Ekpo and John E. U. Ndebbio, Research Paper 44.

Foreign Exchange Bureaus in the Economy of Ghana by Kofi A. Osei, Research Paper 45.

The Balance of Payments as a Monetary Phenomenon: An Econometric Study of Zimbabwe's Experience by Rogers Dhliwayo, Research Paper 46.

Taxation of Financial Assets and Capital Market Development in Nigeria by Eno L. Inanga and Chidozie Emenuga, Research Paper 47.

The Transmission of Savings to Investment in Nigeria by Adedoyin Soyibo, Research Paper 48.

A Statistical Analysis of Foreign Exchange Rate Behaviour in Nigeria's Auction by Genevesi O. Ogiogio, Research Paper 49.

The Behaviour of Income Velocity In Tanzania 1967-1994 by Michael O.A. Ndanshau, Research Paper 50.

Consequences and Limitations of Recent Fiscal Policy in Côte d'Ivoire, by Kouassy Oussou and Bohoun Bouabre, Research Paper 51. 


\title{
Effects of inflation on Ivorian fiscal variables: An econometric investigation
}

\author{
Eugene Kouassi \\ University of Abidjan
}

AERC Research Paper 52

African Economic Research Consortium, Nairobi November, 1996 
The Effects of Exchange Rate Policy on Cameroon's Agricultural Competitiveness by Aloysius Ajab Amin, Research Paper 42.

Policy Consistency and Inflation in Ghana by Nii Kwaku Sowa, Research Paper 43.

Fiscal Operations in a Depressed Economy: Nigeria, $1960-90$ by Akpan H. Ekpo and John E. U. Ndebbio, Research Paper 44.

Foreign Exchange Bureaus in the Economy of Ghana by Kofï A. Osei, Research Paper 45.

The Balance of Payments as a Monetary Phenomenon: An Econometric Study of Zimbabwe's Experience by Rogers Dhliwayo, Research Paper 46.

Taxation of Financial Assets and Capital Market Development in Nigeria by Eno L. Inanga and Chidozie Emenuga, Research Paper 47.

The Transmission of Savings to Investment in Nigeria by Adedoyin Soyibo, Research Paper 48.

A Statistical Analysis of Foreign Exchange Rate Behaviour in Nigeria's Auction by Genevesi O. Ogiogio, Research Papcr 49.

The Behaviour of Income Velocity In Tanzania 1967-1994 by Michael O.A. Ndanshau Research Paper 50.

Consequences and Limitations of Recent Fiscal Policy in Côte d'Troire, by Kouassy Oussou and Bohoun Bouabre, Research Paper 51. 


\title{
Effects of inflation on Ivorian fiscal variables: An econometric investigation
}

\author{
Eugene Kouassi \\ University of Abidjan
}

AERC Research Paper 52

African Economic Research Consortium, Nairobi

November, 1996 
(C) 1996, African Economic Research Consortium.
Published by: The African Economic Research Consortium P.O. Box 62882
Nairobi, Kenya
Printed by: The Regal Press Kenya, Ltd
P.O. Box 46116
Nairobi, Kenya

ISBN 9966-900-88-8 
Contents

$\begin{array}{lr}\text { List of tables } \\ \text { List of figures } \\ \text { Acknowledgements } \\ \text { Abstract } \\ \text { I Introduction } \\ \text { II The inflation process } & 1 \\ \text { III } \quad \text { The Aghevli-Khan model } & 2 \\ \text { IV Empirical results } & 6 \\ \text { V Simulations } & 11 \\ \text { VI Summary, conclusions and cxtensions } & 15 \\ & 17 \\ \text { Appendix } & 18 \\ \text { References } & 19\end{array}$




\section{List of tables}

1. Specification of the model

2. Parameter estimates

\section{List of figures}

Evolution of CPI

Inflation and fiscal deficits

Evolution of revenues and expenditures

Evolution of \% of GDP

5a. Effect on revenues

5b. Effect on expenditures

6a. Effect on revenues

6b. Effect on expenditures 


\section{Acknowledgements}

I am grateful to the African Economic Research Consortium for their financial support In other respects, I am in debt to Prof. B. Decaluwe (University of Laval, Quebec, Canada), Prof. B. Ndulu (AERC, Nairobi, Kenya), Dr. Moshin Kahn (IMF, Washington, D.C.), Prof. C.D. Goodwin (Duke University, USA), Prof. S. O'Connell (Swarthmore College, USA), Prof. David Bevan (University of Oxford, U.K), Prof. P.J. Montiel (Oberlin College, USA) and Dr. Andrew Mullei (ACMS) for their helpful comments and suggestions on the original work. I thank Dr. Brigitte Bocoum (University of West Virginia, USA) for the final translation of the paper into English. However, the opinions expressed here, any missing information and any weaknesses in the paper are exclusively the responsibility of the author. 


\section{Abstract}

This paper analyses the effects of inflation on Ivoiran fiscal variables by using the AghevliKhan model (1978) to estimate the time required for a change in the consumer price index to be fully reflected in the variables. The predictability of time-dependent adjustment coefficients is also investigated using the Kalman filter approach. Simulation experiments (e.g., temporary decrease or increase in GDP) are also used for policy implications. Estimations obtained from the study seem very useful for Côte d'lvoire policy makers. 


\section{Introduction}

The various problems created by inflation have significantly hindered Côte d'Ivoire's economic reform process, which began in 1980. More particularly, in the context of the West African Monetary Union, the direct linkage between the principal instruments of fiscal policy, e.g., government expenditures and revenues, and the price stabilization policy has been detrimental to fiscal policy.

The economic impacts of inflation have been discussed extensively in the literature. Some of the most common factors cited in rising inflation are the increases often associated with the cost of government services and expenditures, the amount of budgetary demands, the amount of revenues collected, debt and debt servicing.

Some researchers have previously attempted to analyse the effect of inflation on fiscal variables for selected developing regions: South and Central America, the Caribbean, Asia and Africa. The major drawback of these studies has been the broadness of their scope, i.e., the lack of specificity of the cases investigated. Other theoretical frameworks have been developed by Barro (1979), Evans (1985) and Wasserfalen (1985) that yielded poor empirical results. Our study develops a methodology based on the Aghevli-Khan model (1978) to estimate the effects of inflation and the adjustment speeds of Ivorian fiscal variables by:

- elaborating a sound theoretical and empirical framework to assess the effects of inflation on the fiscal variables (revenues and expenditures) in Côte d'Ivoire;

- testing the accuracy of the Aghevli-Khan hypothesis in describing the fiscal experience of Côte d'Ivoire; and

- analysing the speed with which fiscal variables adjust to inflation in Côte d'Ivoire.

The study includes the following parts. Section II discusses the salient points of the inflation process and the evolution of fiscal variables in connection with inflation. Section III describes the methodology adopted, a conceptual framework that takes into account the specificities of the economy of Côte d'Ivoire. The initial model is generalized to account for the adjustment speeds (dynamic aspects). Section IV deals with empirical results and their statistical and economic interpretations. An estimation of the effects of inflation on fiscal variables and the adjustment speeds of these variables are also considered. Simulations, final remarks and conclusions are considered in the last two sections. 


\section{The inflation process}

Before dealing with the inflation process, it would be useful to review the macroeconomic context of Cote d'lvoire. The experience of the Ivorian economy during the last three decades provides an interesting modern case study for analysing the dynamics of inflation in the context of fixed parity with the CFA franc. The relative price stability achieved in this context in the West Africa Monetary Union after 1948 was undermined by the rapid monetary expansion resulting from the boom in commodity prices (mainly coffee and cocoa) during the period of 1976-1978 (Figure 1). The pressure on prices was also greatly exacerbated by the recent devaluation (January 1994) of the CFA franc. Government expenditures increased in nominal terms, but declined substantially in real terms.

In the months and years of high inflation, the government increased expenditures in real terms, even as revenues in real terms declined steeply. The decline in revenues was a direct consequence of high inflation, given the structure of taxation and the method of collection tax in Côte d'Ivoire. On the other hand, the main elements in the dynamics of the accelerating phase of Ivorian inflation emerge from the link between the inflation process and the fiscal deficits, the credit policy and the monetary expansion (Figure 2).

Price increases were initiated, and began to be aggravated, by rising government expenditures and their direct effect on food supplies and prices. Since government revenues lagged substantially behind price increases, the authorities were forced to finance their deficits by the creation of money and by borrowing. This self-perpetuating process caused inflation to spiral higher and higher; it has reached the stage of near hyperinflation since 1994.

An explanation of the budgetary problems in Côte d'Ivoire is mapped in Figures 3 and 4 , which illustrate the evolution of expenditures and revenues. It is shown that the revenues fluctuate, with marked changes from the horizontal line in the function of the level of international prices. The ratio between global revenues and GDP was of $4.18 \%$ in $1975,33.93 \%$ in $1978,27.66 \%$ in 1982 and $23.25 \%$ in 1989 . Two factors, interior and external fiscality, essentially explain the evolution of tax revenues.

The evolution of expenditures, on the contrary, has demonstrated a consistent yearly increase, associated with large fluctuations from one year to the next. The ratio between the global government wage bill and the total non-investment budget is $60 \%$. 
Figure 1: Evolution of CPI

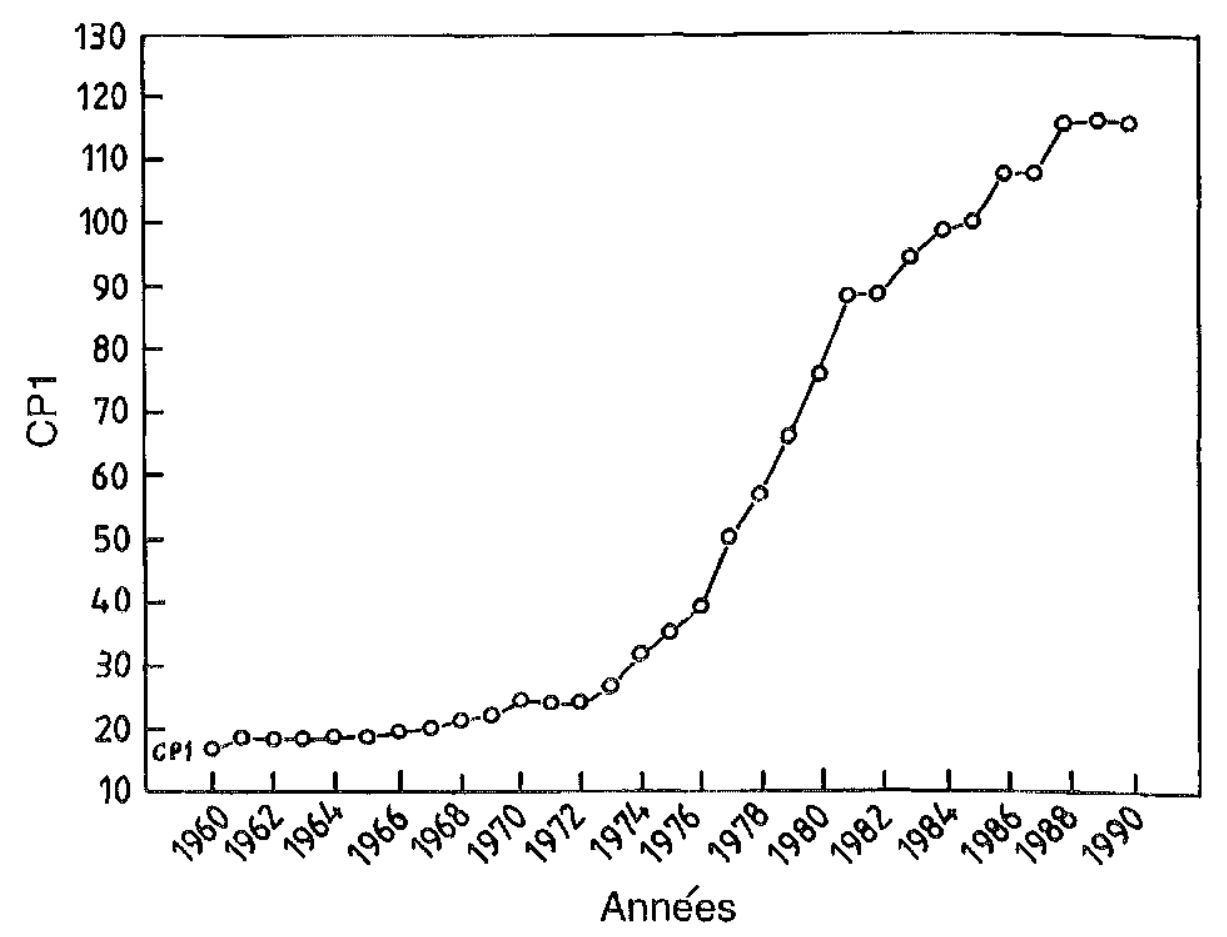

Figure 2: Inflation and fiscal deficits

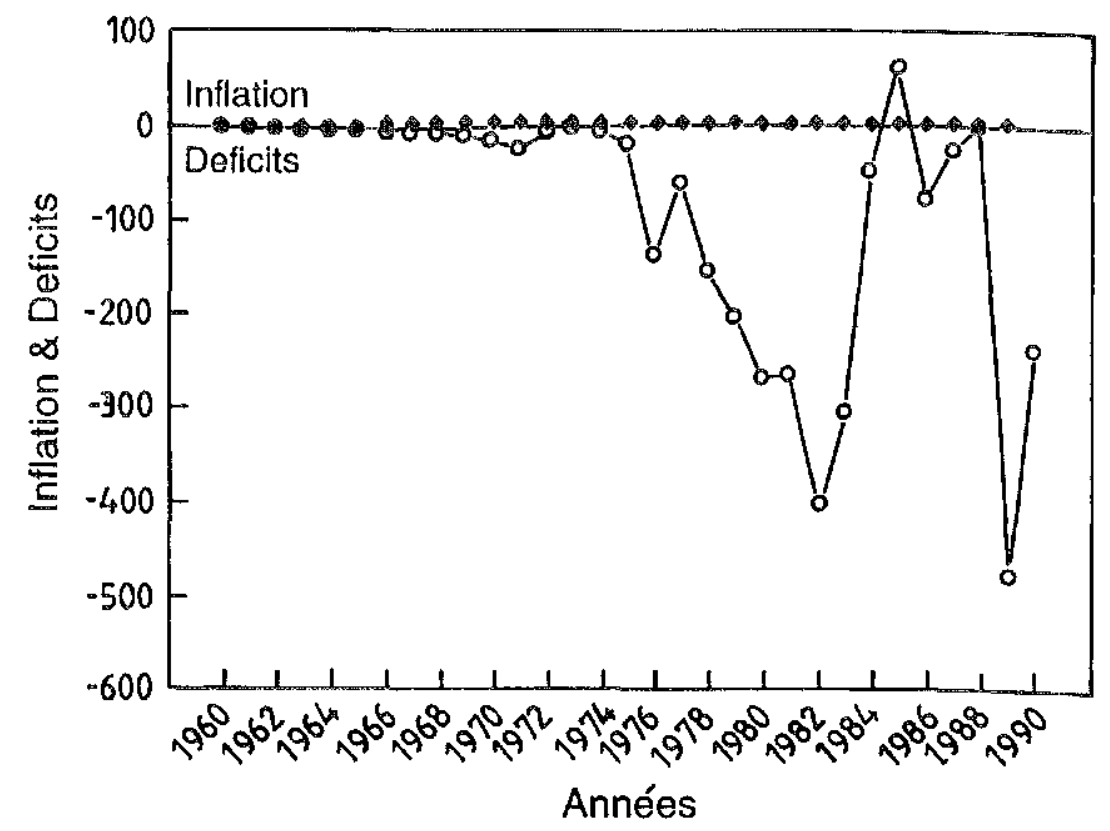


Figure 3: Evolution of revenues and expenditures

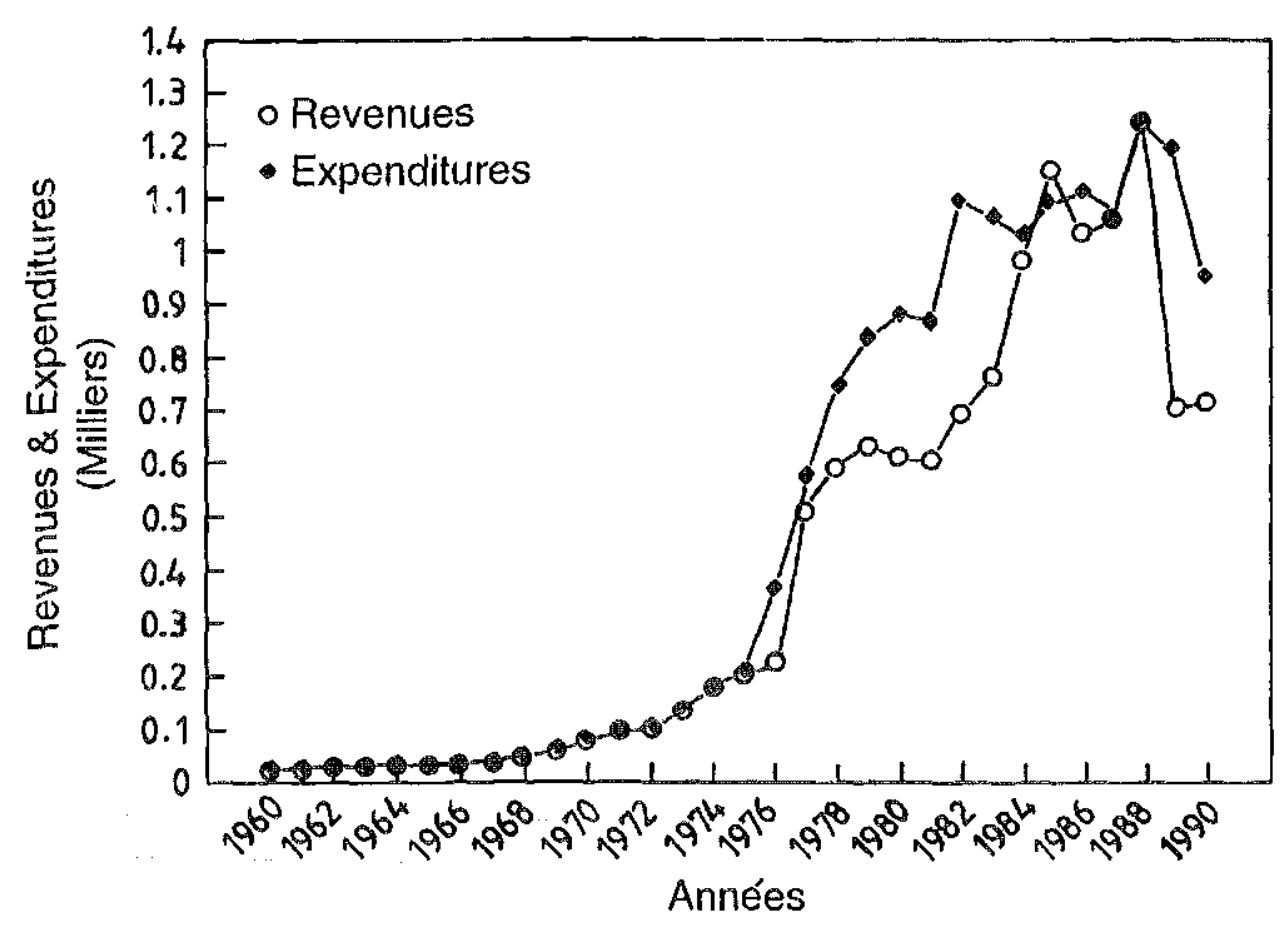

Figure 4: Evolution in \% of GDP

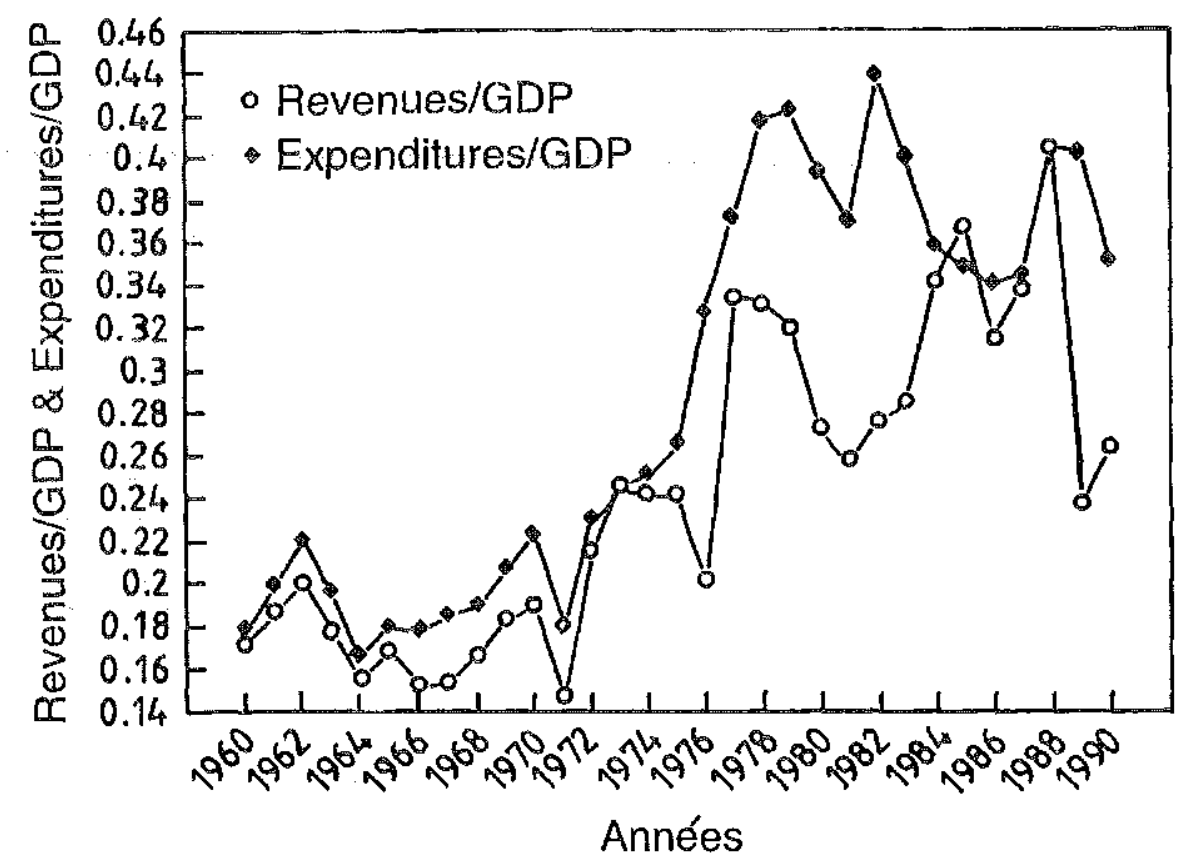

Années 
When taking into account the rate of inflation, preliminary results show that:

- the ratio between revenues and GDP was $34 \%$ in $1975,47 \%$ per cent in 1978 , $27 \%$ in $1982,28.3 \%$ in 1985 and $26 \%$ in 1990 ; and

- the ratio between expenditures and GDP was $34 \%$ in $1975,47 \%$ in $1978,40.3 \%$ in 1985 and $40 \%$ in 1990.

In the first approximation, inflation appears to have increased the wedge between revenues or expenditures and GDP. In the next section, the study scrutinizes the effects of inflation on Ivorian fiscal variables as well as the speeds of adjustment in response to inflation. 


\section{The Aghevli-Khan model}

As stated previously, the present methodology relies on the Aghevli-Khan (1978) model described next. Heller (1980), while attempting to determine the actual net fiscal response to inflation, raised three important questions: 1 . How do policy makers adjust the desired level of nominal expenditure and revenue to a change in the price level in Côte d'Ivoire? 2. How rapidly are such adjustments reflected in decisions pertaining to actual expenditure (or revenue) level? 3. What are the constraints or factors that determine the relative speed of such adjustments?

Within the Aghevli-Khan model, only the first two questions are formally addressed. The last question can find answers using simple economic and social analyses of the lvorian budgetary environment (structure of revenues and expenditures, and the perceived cost of adjustment mechanisms) to try to point out specific factors influencing the responses of expenditures and revenues.

\section{Description}

In its extended form, the model developed by Aghevli and Khan $(1977,1978)$ is based on equations for four factors: price, government expenditures, revenue and money supply. These are described below.

\section{Price equations}

The demand for money is specified as follows:

$$
\begin{gathered}
\log (M / P)=a_{o}+a_{1} \log Y_{1}-a_{2} \Pi_{t} \\
a_{1}, a_{2}>0
\end{gathered}
$$

where:

$\begin{array}{ll}\mathrm{M} & =\text { stock of nominal money balances } \\ \mathrm{P} & =\text { price level } \\ \mathrm{Y} & =\text { level of real income } \\ \Pi_{1} & =\text { expected rate of inflation }\end{array}$


Assuming that prices adjust to the excess demand for money, adjustment of actual stock or real balances to the desired level is specified as:

$$
\Delta \log (M / P)_{t}=K\left[\log (M / P)_{t}^{D}-\log (M / P)_{t-1}\right]
$$

where: $\mathrm{O}<\mathrm{k}<1$ is the stock adjustment coefficient.

The expected rate of inflation is generated by an adaptive expectation scheme specified as:

$$
\Pi_{1}=\lambda \mathrm{DP}_{\mathrm{t}}+(1-\lambda) \Pi_{\mathrm{t}-1}
$$

where: $\lambda=$ coefficient of expectation

$\mathrm{DP}_{1}=$ current rate of inflation

\section{Government expenditures equations}

Desired real government expenditure is specified as:

$$
\log (G / P)_{t}^{D}=g_{0}+g_{1} \log Y_{i}
$$

$g_{1}>0, g_{1}$ is defined as the real income elasticity of expenditure.

Expenditures also follow a stock adjustment process, which is specified as:

$$
\Delta \log (G / P)_{t}^{D}=v\left[\left(\log (G / P)_{t}^{D}-\log (G / P)_{t-1}\right]\right.
$$

where: $0<v<1$ is the adjustment stock.

\section{Government revenues equations}

Desired government revenue is specified as a function of nominal income.

$$
\log (R)_{t}^{D}=t_{0}+t_{1}\left[\log \left(Y_{t}\right)+\log \left(P_{t}\right)\right]
$$

$t_{1}>0, t_{1}$ is defined as the elasticity of revenues.

The adjustment process between desired and actual revenue levels is defined by:

$$
\Delta \log R_{t}=\tau\left[\log R_{t}^{D}-\log R_{t-1}\right]
$$

where: $0<\mathrm{t}<1$ is the adjustment coefficient of revenue. 
Money supply equations

From the consolidated banking system balance sheet, the asset side is taken to present the money supply identity:

$$
\mathrm{M}_{\mathrm{s}}=\mathrm{NFA}+\mathrm{CG}+\mathrm{CP}+\mathrm{O}
$$

where: NFA $=$ net foreign assets

$$
\begin{array}{ll}
\mathrm{CG} & =\text { claims on government } \\
\mathrm{CP} & =\text { credit to the private sector } \\
\mathrm{O} & =\text { other assets. }
\end{array}
$$

In terms of changes, we have:

$$
\Delta \mathrm{M}_{\mathrm{t}}=\Delta \mathrm{NFA}+\Delta \mathrm{CG}+\Delta \mathrm{CP}+\Delta \mathrm{O}
$$

In the most general case, government borrowing from the central bank is for financing the budget deficit. We can therefore cquate the difference between revenue levels to the change in claims on government:

$$
\Delta \mathrm{CG}=\mathrm{G}-\mathrm{R}
$$

Substituting Equation $4 c$ into Equation 4a gives:

$$
\Delta \mathrm{M}_{1}=\Delta \mathrm{NFA}+(\mathrm{G}-\mathrm{R})+\Delta \mathrm{CP}+\Delta \mathrm{O}
$$

According to the general framework of the model, the coefficients of interest are: $v, \tau$, $t_{1}$ and $g_{l}$.

Note that the average time lags are, respectively:

- money demand

$=(1-\mathrm{k}) / \mathrm{k}$

- government expenditure $=(1-v) / v$

- government revenue

$$
=(1-t) / t
$$

We also suppose that the nominal deficit will be a function of the increase in the price level, provided $\tau$ is less than $v$, even though $t_{1}=g_{1}$.

\section{An alternative formulation}

In practice, equations $2 a$ and $2 b$ and $3 a$ and $3 b$ can be estimated using the reduced form. Suppose that in Equations $2 \mathrm{~b}$ and $3 \mathrm{~b} \tau$ and $v$ are directly linked to the rate of inflation 
and the acceleration process (deceleration, respectively) in the inflation process. Then, the Aghevli-Khan model can be rewritten as follows:

$$
\begin{gathered}
\log (G / P)_{t}^{D}=g_{0}+g_{1} \log \left(Y_{t}\right), g_{t}>0 \\
\log R_{t}^{D}=t_{0}+t_{1}\left(\log \left(Y_{t}\right)+\log \left(P_{t}\right)\right), t_{1}>0
\end{gathered}
$$

When Equations 2a and 3a are differentiated, we obtain:

$$
\Delta \log (G / P)_{t}=v\left[\log (G / P)_{t}^{D}-\log (G / P)_{t-1}\right]
$$

$$
\Delta \log R_{t}=\tau\left[\log R_{t}^{D}-\log R_{t-1}\right]
$$

we suppose that: $0<v<1,0<\tau<1$ and $v>t$

Taking into account the fact that:

$$
\Delta \log (G / P)_{1}=\left[\log (G / P)_{1}-\log (G / P)_{t \cdot-}\right]
$$

and substituting Equation 2a into Equation 2b gives:

$$
\log (G / P)_{t}=v g_{0}+v g_{1} \log Y_{t}+(l-v) \log (G / P)_{t, 1}
$$

Otherwise, consider the fact that:

$$
\Delta \log R_{t}=\left[\log R_{t}-\log R_{t-1}\right]
$$

and substituting Equation $3 \mathrm{a}$ into Equation $3 \mathrm{~b}$ gives :

$$
\log R_{t}=\tau t_{0}+\tau t_{l}\left(\log Y_{t}+\log P_{t}\right)+(1-\tau) \log R_{t-1}
$$

The fundamental hypothesis of the model is that expenditure tends to adjust to its desired level more rapidly than revenue, or that $v>\tau$. The model also supposes that the longterm income elasticities of expenditure and revenue, $g_{1}$ and $t_{1}$, respectively, are not necessarily close to unity. The effects of the factors $v$ and $\tau$ may be tested, assuming that they are time-dependent:

and

$$
v_{t}=\alpha_{1} v_{i-1}+\alpha_{2} i_{t}+\alpha_{3} \Delta i_{i}
$$

$$
\tau_{t}=\beta_{1} \tau_{t-1}+\beta_{2} i_{t}+\beta_{3} \Delta i,
$$

where $\mathrm{i}_{\mathrm{t}}=\Delta \log \mathrm{P}_{\mathrm{t}}=$ the rate of inflation in the $\mathrm{t}$ year and $\Delta \mathrm{i}$ is assumed to measure the acceleration or deceleration in the inflation rate since the previous year. Substituting 
Equations 6 and 7 into Equations 4 and 5 yields estimating equations in the form:

$$
\begin{gathered}
\Delta \log (G / P)_{t}=\left(\alpha_{1} v_{t-1}+\alpha_{2} i_{t}+\alpha_{3} \Delta i_{t}\right)\left(g_{0}+g_{1} \log Y_{t} \cdot \log (G / P)_{t-1}\right) \\
\Delta \log R_{t}=\left(\beta_{1} t_{t-1}+\beta_{2} i_{t}+\beta_{3} \Delta i_{t}\right)\left(t_{0}+t_{1} \log \left(Y P_{t}\right) \log R_{t-1}\right)
\end{gathered}
$$

Another issue considered in the model is that the speed of adjustment to inflation is determined by whether the inflation rate has been anticipated. The model in Equation $2 \mathrm{a}$ is therefore rewritten in such a way that desired nominal expenditure in a period, $\mathrm{G}^{\mathrm{D}}{ }_{\mathrm{t}}$, is a function of the price level in that period, viz.,

$$
\log (G)_{t}^{D}=\log P_{t}+g_{0}+g_{1} \log Y_{t}
$$

or

$$
G_{i}^{D}=G^{D}\left(P_{i}, Y_{t}\right)
$$

If the expected price level $P$ differs from the actual price level that is realized, $P_{t}^{e}$, we will have $G_{t}^{D}\left(P_{t}^{a}\right)>G_{T}^{D}\left(P_{t}^{a}\right)$ if $P_{t}^{a}>P_{t}^{\prime}$. The change in actual nominal expenditures between $t$ and $t-1$ is assumed to reflect both an adjustment of $u_{1} \%$ of the difference between $G_{t}^{D}\left(P_{t}^{e}\right)$ and $G_{t-1}$, reflecting the response to anticipated inflation, and $\mathrm{u}_{2} \%$ of the difference between $G_{t}^{D}\left(P_{t}^{a}\right)$ and $G_{t}^{D}\left(P_{t}^{c}\right)$, reflecting the response to the unanticipated inflation during the period:

$$
\Delta \log G_{t}=v_{1}\left(\log G^{D}\left(P_{1}^{e}\right)-\log G_{t-1}\right)+v_{2}\left(\log G^{D}\left(P_{t}^{a}\right)-\log G^{D}\left(P_{t}^{e}\right)\right)
$$

Analogously,

$\Delta \log R_{t}=\tau_{1}\left(\log R^{D}\left(P_{t}^{e}\right)-\log R_{t-1}\right)+\tau_{2}\left(\log R^{D}\left(P_{t}^{a}\right)-\log R^{D}\left(P_{t}^{e}\right)\right)$

Combining Equations 10 and 11 and Equations 3a and 12, respectively, we obtain:

$$
\begin{aligned}
& \left.G_{t}=v_{1} g_{0}+\left(1-v_{1}\right) \log G_{t-1}+v_{1} \log P_{t}^{e}\right)+v_{1} \log P_{t}^{e}+v_{1} g_{1} \log Y_{t} \\
& \text { and } \quad \log R_{t}=v_{1} t_{0}+\left(1-\tau_{1}\right) \log R_{t-1}+\tau_{1} t_{1} \log \left(Y_{t} P_{t}^{e}\right)+\tau_{2} t_{1} \log \left(P_{t}^{a} / P_{t}^{e}\right)
\end{aligned}
$$

The expected rate of inflation is obtained by:

$$
\Pi_{t}=\frac{P_{t}^{e}}{P_{t-1}}=\beta \Delta \log P_{t}+(1-\beta) \Pi_{t-1}
$$




\section{Empirical results}

\section{Estimating and testing for the effects of inflation}

The model estimated can be summarized as follows:

Table 1: Specification of the model

Prices: $\log (M / P)=a_{0}+a_{1} \log Y_{t}+a_{2} \pi_{t}$

Government expenditures: $\log (G / P)=v g_{0}+v g_{1} \log Y_{1}+(1-v) \log (G / P)_{t-1}$

Government revenues: $\log R_{t}=\tau t_{0}+\tau t_{1}\left(\log Y_{t} P_{t}\right)+(1-\tau) \log R_{t-1}$

Expected inflation: $\Delta \pi_{t}=\lambda\left[P_{t-1}-\pi_{t-1}\right]$

Money supply: $M_{t}=N F A+C G+C P+O$

Real money balances: $m_{1}=M / P$

This model was identified using linear homogeneous restrictions and order and rank conditions. Since the same expected inflation and price equations appear in the different equations, the criterion of efficient estimation requires the imposition of appropriate across-equation restrictions.

This is accomplished by employing a full information maximum likelihood (FIML) estimator that allows non-linear constraints to be placed on parameters both within and across equations. The FIML estimation method that is used, however, requires that the model be linear in variables. For estimation purposes, and for analysing questions of the dynamic stability of the model, the money identity can be approximated (e.g., Khan and Knight, 1983) by the relationship:

$$
\begin{aligned}
\gamma_{1} \log M_{t}= & \log M_{t-1}+\gamma_{2}\left[\log \varepsilon_{t}+\log R\right]-\gamma_{3}\left[\log E_{t-1}+\log R_{t-1}\right] \\
& +\gamma_{4} \log D C_{1}-\gamma_{5} \log D C_{t-1}+\gamma_{6}
\end{aligned}
$$

where: $\mathrm{DC}=$ domestic credit

$\varepsilon_{t}=$ exchange rate per units of domestic currency per unit of foreign currency. 
Table 2: Parameter estimates

Parameters

Prices

$\begin{array}{llll}\text { Money demand } & & & \\ \text { Adjustment } & \lambda & =0.0015 & 2.918 \\ \text { Income elasticity } & a_{1} & =0.413 & 4.156 \\ \text { Expected inflation } & a_{2} & =5.127 & -4.503 \\ \text { Constant } & a_{0} & =5.272 & 4.217 \\ \text { V N ratio } & =2.158 & \\ \text { Residual sum } & =0.016 & \\ \text { Residual variance } & =0.0212 & \\ \text { Sum of absolute errors } & =3.0538\end{array}$

Government expenditures

\begin{tabular}{|c|c|c|c|}
\hline Adjustment & & $=0.999$ & 10.200 \\
\hline Income elasticity & $g_{1}$ & $=0.565$ & 5.9180 \\
\hline Constant & $g_{0}$ & $=2.206$ & 2.404 \\
\hline VN ratio & & $=2.085$ & \\
\hline Residual sum & & $=-0.035$ & \\
\hline Residual variance & & $=0.0044$ & \\
\hline Sum of absolute errors & & $=1.453$ & \\
\hline
\end{tabular}

Government revenues

$\begin{array}{lll}\text { Adjustment } & t=0.964 & 14.677 \\ \text { Income elasticity } & t_{t}=0.809 & 11.277 \\ \text { Constant } & t_{0}=1.680 & 0.4085 \\ \text { VN ratio } & =0.325 & \\ \text { Residual sum } & =-0.036 & \\ \text { Residual variance } & =0.0217 & \\ \text { Sum of absolute errors } & =3.501\end{array}$

The constant terms in each equation were not constrained, and are thus reported in their composite forms. To give some idea of the goodness of fit of each of the equations, the respective Von Neumann ratio (VN ratio), the residual variance, the residual sum and the sum of absolute errors, and the corresponding variances of the dependent variables $\left(\mathrm{s}_{y}{ }^{2}\right)$ are presented. The corresponding $\mathrm{R}^{2}$ are not reported since, in simultaneous estimation, the $\mathrm{R}^{2}$ is bounded $(-\infty, 1)$ and not bounded $(0,1)$.

In this table, the variance of the level of the dependent variable estimated equation is presented with some statistics of goodness-of-fit (VN ratio, residual sum, residual variance, sum of absolute errors). 
Finally, given that the model is dynamic and involves fecdback, it's important to investigate for its asymptotic stability. For this reason, the eigensystem of the estimated model was calculated. All the modules are less than unity and thercfore the estimated model can be considered dynamically stable. But the stability of the system is apparently sensitive to the parameters in the prices equation.

The coefficients of adjustment are positive and lie between 0 and 1 . The sign of the elasticity of revenues agrees with our expectation; this elasticity is $t_{1}=0.809$ and is statistically significant. The elasticity does not exceed one and suggests that with an increase in the price level, decision makers desire an increased real tax burden, even if the real income remains unchanged. The sign of the elasticity of expenditures also agrees with expectations and is $g_{1}=0.565$, which implies that decision makers desire an increased real burden if the price level increases, ceteris paribus.

While this may be the effects of inflation on a given tax system, it is obvious that it may not reflect the objectives of the government since the relative change in expenditures is comparatively less important than the relative change in revenues. The Aghevli-Khan hypothesis that expenditures adjust more rapidly than revenues seems valid even in the case of Côte d'lvoire. The model is also accurate in the estimation of the adjustment coefficients since across and within restrictions have been imposed on the structural parameters and on adjustment speeds for convergence reasons.

These results can be interpreted in the sense that when inflation is becoming important the decision makers would like to adjust the levels of the budget; but the adjustment is such that expenditures adjust more rapidly than revenues. It is also important to notice that Côte d'Ivoire decision makers adjust the levels of expenditures as soon as they sec that inflation is becoming more and more important. In Côte d'Ivoire, these adjustments suppose some budgetary restrictions, in the absence of transfers and other taxes.

\section{Estimating time-dependent speeds of adjustment}

To investigate the predictability of the speed of adjustment to inflation, the Kalman filter has been used. The method used to that purpose is the "prediction-correction" method of the Kalman filter:

The two systems of equations estimated are:

(I)

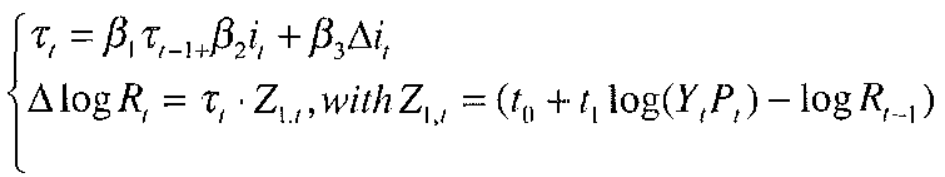

and

(II) $\left\{\begin{array}{l}v_{t}=\alpha_{1} v_{t-1}+\alpha_{2} i_{1}+\alpha_{3} \Delta i_{t} \\ \Delta \log (G / P)_{t-1}=v_{1} Z_{2, t}, \text { with } Z_{2, t}=\left(g_{0}+g_{1} \log Y_{t}-\log (G / P)_{t-1}\right)\end{array}\right.$ 
with the restrictions:

where:

$0<v_{t}<1,0<\tau_{t}<1$ and $v_{t}>\tau_{t}$

$\tau_{\mathrm{t}}=$ time-dependent revenue adjustment coefficient
$v_{\mathrm{t}}=$ time-dependent expenditure adjustment coefficient
$i_{\mathrm{t}}=\Delta \log \mathrm{P}_{\mathrm{t}}, \Delta \mathrm{i}_{\mathrm{t}}=\Delta^{2} \log \mathrm{P}_{\mathrm{t}}$

Estimations of systems I and II were carried out using the Kalman filter. The filters were initialized using a diffuse prior, i.e., $\tau_{0}=0, v_{0}=0$

$$
\begin{aligned}
& \text { and } \quad \sum^{v_{0}}\left(\operatorname{resp} \cdot \sum^{v_{0}}\right)=x \mathrm{I}_{k} \text {, where } x=10^{4} \\
& \text { and } \quad \mathrm{I}_{\mathrm{k}}=1 \text { the variance }
\end{aligned}
$$

Preliminary results were not satisfactory. We decided to impose restrictions on coefficients, i.e., $\alpha_{1}=\beta_{1}=1$. Results are summarized as follows:

$$
\begin{array}{r}
\tau_{t}=0.0026+\tau_{t-1}+1.41 i_{t}-0.943 \Delta i_{t} \\
(3.614)(0.9392) \\
v_{t}=-0.045+v_{t-1}+0.881 i_{t}-1.45 \Delta i_{t} \\
(3.502)(3.236)
\end{array}
$$

( $\mathrm{t}$ in parentheses)

These results have been used to forecast $t_{1}$ and $u_{t}$ :

\begin{tabular}{lllll} 
Years & $t_{1}$ & MAE & MSE & RMSE \\
\hline 1991 & 0.854 & 0.0675 & 0.041 & 0.173 \\
1992 & 0.991 & 0.0041 & 0.0376 & 0.1654 \\
1993 & 0.953 & 0.0153 & 0.0275 & 0.1873 \\
& & & & \\
Years & $n_{1}$ & MAE & MSE & RMSE \\
& & & & \\
1991 & 0.998 & 0.783 & 0.057 & 0.1699 \\
1992 & 0.997 & 0.00513 & 0.0438 & 0.1532 \\
1993 & 0.998 & 0.00431 & 0.0371 & 0.1843 \\
\hline
\end{tabular}

Note: The estimation procedure of time-dependent adjustment coefficients has used the method of signal decomposition developed by Kalman (1960). To evaluate the forecast's performance we have analysed the bias (ME or mean error) and the accuracy of the model using three statistics based on the errors (i.e, MAE or mean absolute error, MSE or mean square error, RMSE or root mean square error). The biases are close to zero and the other statistics indicate a high accuracy of the model in the prediction of the time-dependent adjustment coefficients. 


\section{Simulations}

This section considers the impact of GDP policy shocks on the Ivorian economy, using the point estimates of the parameters presented in the previous section. A baseline case is obtained, and deviations of the path of the economy from the baseline in response to changes in policy variables are analysed.

\section{Temporary decrease in GDP of $10 \%$}

The effects of a fully expected $10 \%$ decrease in GDP on the budget of Cote d'Tvoire are shown in Figure 5. The decrease in GDP, by increasing the initial budget deficit, has an immediate direct effect on the budget. The elasticities of revenues $\left(t_{1}=0.891\right)$ and expenditures $\left(\mathrm{g}_{1}=0.6012\right)$ increase in general. This raises money demand in the current year and increases real excess balances, partly offsetting the direct positive impact of higher government spending.

Figure 5a: Effect on revenues

Revenues \& Revenues SIM2

$$
\text { (Milliers) }
$$

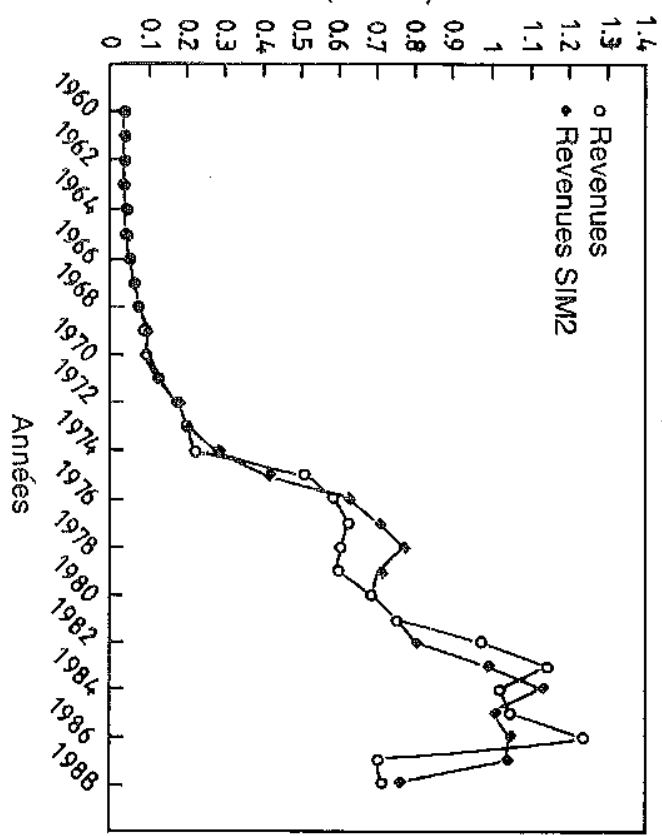

Figure 5b: Effect on expenditures

$$
\text { Expenditures \& Expenditures SIM2 }
$$

$$
\text { (Milliers) }
$$

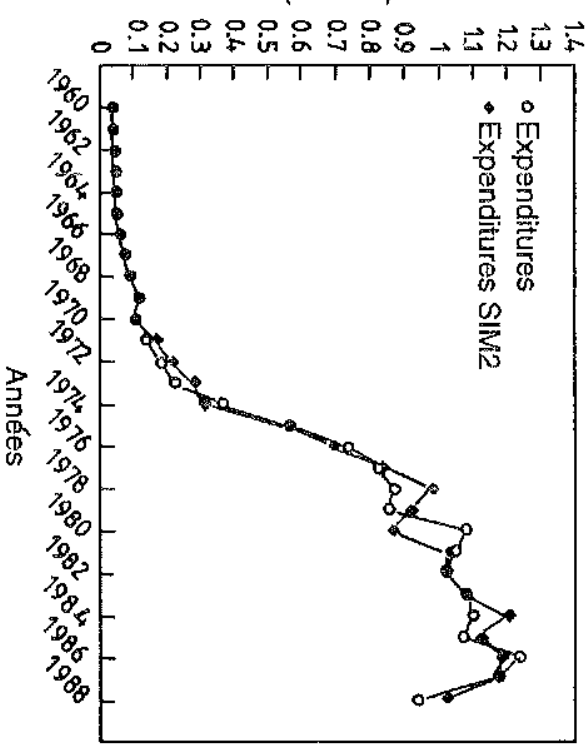




\section{Temporary increase in GDP of $10 \%$}

Finally, we consider the impact of a fully expected increase in GDF of $10 \%$ (Figure 6). The immediate impact of an increase in GDP is a rise in the revenues $\left(t_{1}=0.8782\right)$ and expenditures $\left(\mathrm{g}_{1}=0.573\right)$ of the government budget. The important lesson to be considered here is that in the case of either increase or decrease of the GDP, the government would like to increase its revenues and expenditures but with different proportions. Although it is difficult to discern unidirectional causality effects (or feedback) in the studies mentioned above, the simulation exercises reported in this paper seem to corroborate to some extent the empirical regularities discussed by the World Bank and the IMF regarding sustainable growth in Cote d'Ivoire. They suggest economic and social measures that could have some direct and immediate impacts on the budget deficits.

Figure 6a: Effect on revenues

Revenues \& Revenues SIM$$
\text { (Milliers) }
$$

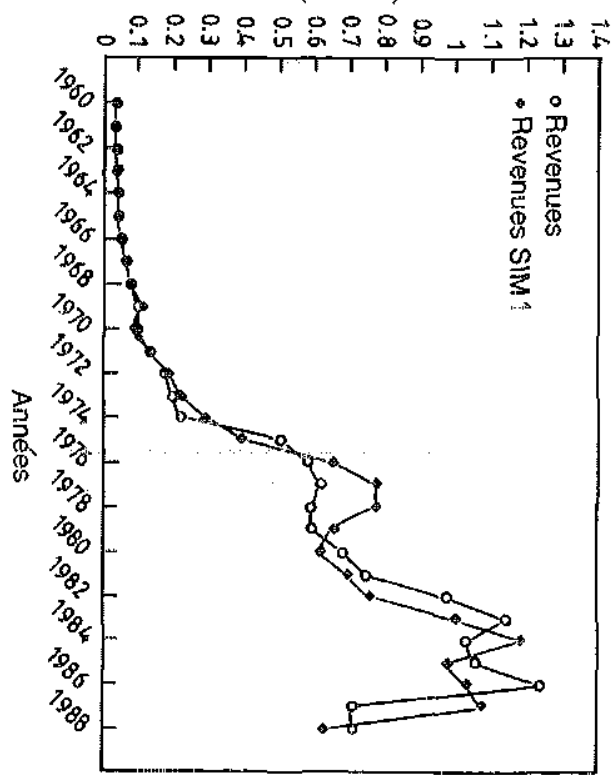

Figure 6b: Effect on expenditures

Expenditures \& Expenditures SIM1 (Milliers)

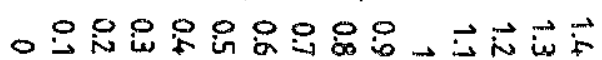

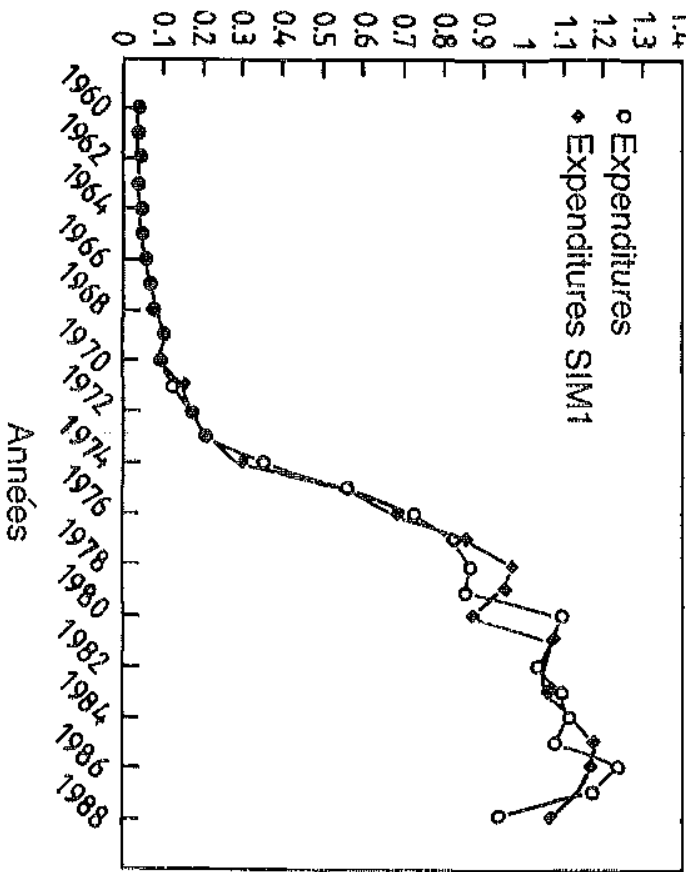




\section{Summary, conclusions and extensions}

The purpose of this paper has been to develop, estimate and simulate a macro-econometric model for Cote d'Ivoire. The parameter estimates have been used to analyse the effects of alternative GDP policy measures on the country's economy.

This model has been successful for Cote d'Ivoire. The key policy implications of the model can be summarized as follows. First, Cote d'Ivoire decision planners adjust the levels of revenues and expenditures when inflation is becoming more and more important. The basic hypothesis was that, while government expenditures rise concomitantly with inflation, government revenues tend to fall behind in real terms owing to collection lags. The financing of this inflation-induced deficit would then increase the money supply and generate further inflation. The second major implication of the model relates to time-dependent adjustment speeds. In general in Cote d'Ivoire, expenditures adjust more rapidly than revenues.

Finally, although the framework developed in this paper provides many insights, there are several areas in which further work is both necessary and desirable. The estimation results do not provide strong support regarding the existence of policy-induced disequilibrium between revenues and expenditures. The demand for money in the AghevliKhan model does not account for interest rates and exchange rates (portfolio selection) or terms of trade. Finally, there is a strong reason to develop an extension of the AghevliKhan model in order to incorporate the determinants of revenue in the overall model. 


\section{Appendix}

Revenues, expenditures and CPI for Cote d'Ivoire 1960-1990 (in billions FCFA)

\begin{tabular}{lrrrr} 
Years & Revenues & Expenditures & CPI & GDP \\
\hline 1960 & 23.2 & 24.0 & 16.7 & 133.92 \\
1961 & 28.4 & 30.2 & 18.8 & 151.63 \\
1962 & 31.8 & 34.9 & 18.4 & 158.10 \\
1963 & 33.2 & 36.5 & 18.6 & 186.40 \\
1964 & 35.0 & 37.3 & 18.7 & 225.68 \\
1965 & 38.0 & 40.6 & 18.9 & 225.40 \\
1966 & 38.5 & 44.5 & 20.0 & 251.60 \\
1967 & 40.9 & 49.2 & 20.4 & 266.40 \\
1968 & 52.7 & 60.0 & 21.5 & 317.20 \\
1969 & 65.1 & 73.1 & 22.5 & 353.90 \\
1970 & 76.1 & 89.7 & 24.6 & 402.30 \\
1971 & 93.5 & 114.0 & 24.2 & 636.20 \\
1972 & 100.1 & 106.4 & 24.3 & 466.10 \\
1973 & 136.6 & 136.5 & 27.0 & 559.10 \\
1974 & 177.6 & 184.5 & 31.7 & 739.00 \\
1975 & 201.8 & 220.4 & 35.3 & 836.50 \\
1976 & 224.8 & 362.7 & 39.5 & 1116.00 \\
$1977 \ldots$ & 511.6 & 568.0 & 50.4 & 1539.20 \\
1978 & 588.0 & 737.9 & 56.9 & 1782.80 \\
1979 & 625.5 & 826.4 & 66.4 & 1964.90 \\
1980 & 605.1 & 869.9 & 76.1 & 2222.00 \\
1981 & 597.3 & 857.0 & 88.2 & 2323.20 \\
1982 & 688.0 & 1089.0 & 88.9 & 2492.90 \\
1983 & 754.0 & 1057.0 & 94.2 & 2652.90 \\
1984 & 967.0 & 1024.0 & 98.2 & 2869.30 \\
1985 & 1149.0 & 1086.0 & 100.0 & 3136.80 \\
1986 & 1026.0 & 1104.0 & 107.3 & 3266.30 \\
1987 & 1052.0 & 1138.0 & 107.7 & 3117.70 \\
1988 & 1243.0 & 1242.3 & 115.3 & 3067.10 \\
1989 & 702.0 & 1180.0 & 116.1 & 2951.60 \\
1990 & 711.4 & 945.7 & 115.66 & 2702.30 \\
\hline & & & &
\end{tabular}




\section{References}

Abbas, K. 1992. "The effects of rate and variability of Inflation on output growth variability: Evidence from selected countries". Pakistan Development Review, Vol. 31, no. 4 .

Aghevli, B.B. and M.S. Khan, 1977. "Inflationary finance and the dynamics of inflation: Indonesia, 1951-72". AER, 67, 390-403.

1978. "Government deficits and the inflationary process in developing countries". IMF Staff Papers, 25, 383-416.

Andersen, L. C. and J.L. Jordan. 1986. "Monetary and fiscal actions: A test of their relative importance in economic stabilization". Federal Reserve Bank St-Louis Rev., 68(8), 29-44.

Antoniadis, A., J. Burruyer, R. Carmona. 1992. "Regression non-lineaire et applications". Collection Economie et Statistiques Avancees.

Barro, R. 1974. "Are government bonds net wealth?". Journal of Political Economy, vol. 82.

1979. "On the determination of the public debt". Journal of Political Economy, vol. 87, 319-337.

Blinder, S. and R. Solow, 1973. "Does fiscal policy matter?". Joumal of Public Economics, vol. 2, 319-337.

Bourguignon, F., W. Branson and J. De Melo. 1989. "Adjustment and income Distribution". World Bank, PPR Working Paper, no 215.

and J.C. Berthelemy, 1990. "Growth and crisis in Cote d'Tvoire". Mimeo Delta.

Choudry, N. 1968. "Integration of budgetary and monetary sectors in the econometric model: Analysis and empirical findings". IMF Staff Papers, July.

DCGTX-CI. 1990. "Fiscalite et competitivite en Cote d'Ivoire". Abidjan Mars.

Deverajan, S. and J. De Melo. 1987. "Adjustment with fixed exchange rate: Case of Cameroon, Cote d'Ivoire and Senegal". World Bank Economic Review, vol. 1.

Durefle, M. 1968. "La crise et la politique d'Ajustement structurel en Cote d'Ivoire". Ministere Francais de la Cooperation, Paris.

Dwyer, G. Jr. 1982. "Inflation and government deficits". Economic Inquiry, 315-329.

Evans L. 1985. "Do large deficits produce high interest rate?", $A E R$, vol. 75.

Glewwe, P. 1987. "La repartition des niveaux de vie en Cole d'Ivoire en 1985", LSMS Working Paper; no. 29.

Geol, R.K. and R. Ram. 1993. "Inflation and relative-price variability: The effect of commodity agregation". Applied Economics, 52, May 1993.

Hagne, N.U., K. Lahiri and P.J. Moneit. 1990. "A macro econometric model for developing 
Countries". IMF Staff Papers, 37, 537-559.

Hazilla. M. and R.J. Kopp. 1986. "Systematic effects of capital service price definition on perceptions of Input substitution", Jounal of Business and Economics Statistics, 4, 209-223.

Kanbur, R. 1990. "Poverty and social dimensions of structural adjustment in Cote d'Ivoire", ADA, Working Paper, 1990.

Lucas, R.E. 1973. "Some-international evidence on output - Inflation trade-offs", $A E R$, June.

1986. "Principes of fiscal and monetary policy". Journal Monetary Economics, 17 (1), 1 17-134.

Ministere Francais de la Cooperation, "Desequilibres structurels et Programmes d'Ajustement en Cote d'Tvoire", Paris, France, 1986.

Modigliani, F. 1980. "Comment on the determination of long term interest rates: implications for monetary and fiscal policies". Journal of Money, Credit and Banking, Special Issue, 12 (2), 370-373.

Montiel, P.J. 1989. "Empirical analysis of high inflation episodes in Argentina, Brazil and Israel". IMF Staff Papers, 36, 527-549.

Khan, M.S. and M.D. Knight, 1982. "Unauticipated monetary growth and inflationary finance". Joumal of Money, Credit and Banking, 14, 347-364 1983. "Stabilization Programs in Developing Countries: A Formal Framework". IMF Staff Papers, 28, 1-53.

1975. "The monetary dynamics of hyper-inflation", Journal of Monetary Economics. 1, 355-362.

Peter S. H. 1980. "Impact of inflation on fiscal policy in developing countries", IMF Staff Papers. 27, 712-748.

1975. "A model of fiscal behaviour in developing counries: Aid, investment and taxation". AER, 65, 429-665.

Sheffrin, S.M. and L. Ynlin. 1990. "Historical changes in inflation-output dynamics: A cross-country study". Joumal of Macro-economics, 12, 47-63.

Tanzio, V.1977. "Inflation, real tax revenue and the case for inflationary finance: theory with appplication to Argentina". IMF Staff Papers, 25, 417-451.

Wasserfalen, W. 1985. "Forecasting, rational expectations and the Phillips Curve: An empirical investigation". Joumal of Monetary Economics, 15, 7-27. 


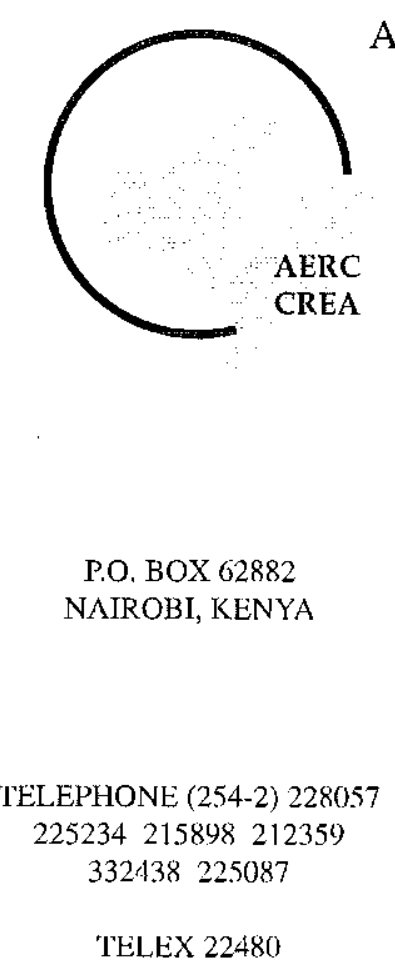

FAX (254-2) 219308

E-MAIL acrc@elci.gn.apc,org oraerc@form-net.com
AFRICAN ECONOMIC RESEARCH CONSORTIUM

The principal objective of the African Economic Research Consortium (AERC), established in August 1988, is to strengthen local capacity for conducting independent, rigorous inquiry into problems pertinent to the management of economies in Sub-Saharan Africa.

In response to special needs of the region, AERC has adopted a flexible approach to improve the technical skills of local researchers, allow for regional determination of research priorities, strengthen national institutions concerned with economic policy research, and facilitate closer ties between researchers and policy makers.

Since its establishment, AERC has been supported by privale foundations, bilateral aid agencies and international organizations.

SPECIAL PAPERS contain the findings of commissioned studies in furtherance of AERC's programmes for rescarch, Iraining and capacity building.

RESEARCH PAPERS contain the edited and externally reviewed results of research financed by the AERC.

It is AERC's policy that authors of Special and Research Papers are free to use material contained therein in other publications. Views expressed in the Special and Research Papers are those of the authors alone and should not be attributed to the AERC's sponsoring Members, Advisory Committee, or Secretariat.

Further information concerning the AERC and additional copies of Special and Research Papers can be obtained by writing to: African Economic Research Consortium, P.O. Box 62882, Nairobi, Kenya. 
This work is licensed under a

Creative Commons

Attribution - NonCommercial - NoDerivs 3.0 Licence.

To view a copy of the licence please see:

http://creativecommons.org/licenses/by-nc-nd/3.0/ 